\title{
FACTORS AFFECTING LABOUR PRODUCTIVITY IN BUILDING PROJECTS IN THE GAZA STRIP
}

\author{
Adnan Enshassi ${ }^{1}$, Sherif Mohamed ${ }^{2}$, Ziad Abu Mustafa $^{1}$ and Peter Eduard Mayer ${ }^{3}$ \\ ${ }^{1}$ School of Civil Engineering, Islamic University of Gaza, P.O. Box 108, Gaza, Palestine \\ ${ }^{2}$ School of Engineering, Griffith University, Gold Coast Campus, QLD 4222, Australia \\ ${ }^{3}$ Projektmanagement und Baurecht, Technische Universität München, Arcisstraße 21, \\ D-80333 München, Germany
}

Received 16 Jan 2007; accepted 06 June 2007

\begin{abstract}
Productivity remains an intriguing subject and a dominant issue in the construction sector, promising cost savings and efficient usage of resources. Productivity is one of the most important issues in both developed and developing countries. The developed countries are aware of the importance of economic growth and social welfare. The developing countries which face unemployment problems, inflation and resource scarcity seek to utilise resources and in such a way to achieve economic growth and improve citizens' lives. Productivity is an issue of particular importance to projects located within the Gaza Strip, as it is considered a newly-developed area, and a huge number of projects have been planned for the near future. The aim of this research is to identify factors affecting labour productivity within building projects, and to rank these factors according to their relative importance from a contractor's viewpoint. The analysis of 45 factors considered in a survey indicates that the main factors negatively affecting labour productivity are: material shortage, lack of labour experience, lack of labour surveillance, misunderstandings between labour and superintendent, and drawings and specification alteration during execution.
\end{abstract}

Keywords: productivity, labour, building projects, improvement.

\section{Introduction}

There is no doubt that construction is a key activity within any economy; it influences, and is influenced by, the nation's gross domestic product (GDP) (Cox et al, 1998, cited in Madi, 2003). Given the uncertainties, management is to deal with, the construction industry is a risky one. While these risks may be derived from either external or internal factors, external factors have a greater influence on construction industry than the internal ones (Zhi, 1995).

The construction sector in Palestine experienced a considerable growth in the aftermath of 1967; its share of GDP increased from less than $9 \%$ in 1985 to more than $23 \%$ in 1995. During that period the sector's contribution fluctuated in an upward long-run trend bounded by $9 \%$ and $19 \%$ from 1970 to 1980 , and by $15,2 \%$ and $23 \%$ from 1989 to 1995 (PECDAR, 1997). However, it appears that in 2004 the construction sector's contribution to the GDP was reduced to $9 \%$ due to the second Intifada in Palestine (World Bank, 2004; PCBS, 2004).

Due to increased demand from the first Intifada, and to accommodate Palestinian returnees from the Gulf following the first Gulf War, the construction sector experienced a steady increase from 1991 onwards. The 1994 peace process accelerated this increase, particularly after the return of many Palestinians with the Palestinian National Authority (MAS, 2001). Expansion of construction activities has generated numerous jobs for skilled, semi-skilled, and unskilled labour. Fig 1 shows the distribution of the labour force within the construction sector from 1997 to 2001 (PASSIA, 2002). Building construction is one of the pioneer sectors that achieved high growth rates during the last two decades, and played a crucial role in absorbing gradual injections into the Palestinian labour force (PCBS, 2004).

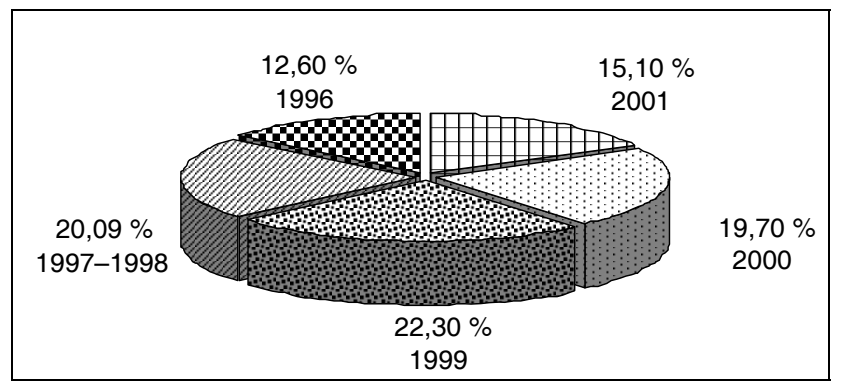

Fig 1. Labour forces employed in the Palestinian construction industry (PASSIA, 2002)

\section{Productivity background}

Improving productivity is a major concern for any profit-oriented organisation, as representing the effective and efficient conversion of resources into marketable products and determining business profitability (Wilcox et al, 2000). Consequently, considerable effort has been directed to understanding the productivity concept, with 
the different approaches taken by researchers resulting in a wide variety of definitions of productivity (Lema, 1995; Pilcher, 1997; Oglesby, 2002). Productivity has been generally defined as the ratio of outputs to inputs.

Construction projects are mostly labour-based with basic hand tools and equipment, as labour costs comprise 30 to $50 \%$ of overall projects costs (Guhathakurta and Yates, 1993). Therefore, while numerous construction labour productivity research studies have been undertaken, only a few have addressed the productivity issue in developing countries. Lema (1995) observed that labour productivity data were not available from Tanzanian construction established on the basis of actual site observations. Accordingly, on the basis of limited data, it was concluded that labour utilisation on construction sites was less than $30 \%$ in Tanzania.

Olomolaiye et al (1998) briefly studied labour productivity on construction sites in Nigeria. Their study concluded that there was a need for establishing output figures on various construction sites through time study techniques. It was concluded that method studies and research results should be disseminated not only to large firms but also to small firms so the most productive working methods (or best practices) could be adopted by operatives, resulting in increased output without necessarily increasing physical efforts.

Lim et al (1995) studied factors affecting productivity in the construction industry in Singapore. Their findings indicated that the most important problems affecting productivity were: difficulty with recruitment of supervisors; difficulty with recruitment of workers; high rate of labour turnover; absenteeism from the work site; and communication problems with foreign workers. Olomolaiye et al (1996) studied factors affecting productivity of craftsmen in Indonesia, with their findings indicating craftsmen in Indonesia spent $75 \%$ of their time working productively. Five specific productivity problems were identified: ie lack of materials; rework; absenteeism; lack of equipment; and tools.

\section{Factors affecting construction productivity}

The factors influencing construction productivity have been the subject of inquiry by many researchers. In order to improve productivity, a study of the factors affecting it, whether positively or negatively, is necessary. Making use of those factors that positively affect productivity and eliminating (or controlling) factors that have a negative effect, will ultimately improve productivity. If all factors influencing productivity are known, it will also be possible to forecast productivity (Lema, 1995). Several researchers have investigated the factors influencing labour productivity (United Nations, 1965; Thomas et al, 1991; Lim et al, 1995; Lema, 1995; Olomolaiye et al, 1996; Heizer and Render, 1996; Olomolaiye et al, 1998; Kaming et al, 1998; Teicholz, 2001; Thomas and Sanders, 1991; Wachira, 1999; Rojas and Aramvareekul, 2003). Despite such intensive investigations, researchers have not agreed on a universal set of factors with significant influence on productivity; or any agreement has been reached on the classification of these factors.
Several approaches have been adopted in relation to the classification of factors affecting construction productivity. A United Nations report (1995) stated that in ordinary situations two major sets of factors affect the site labour productivity requirements: organisational continuity and execution continuity. Organisational continuity encompasses physical components of work, specification requirements, design details etc. Execution continuity relates to the work environment and how effectively a job is organised and managed. Management aspects include weather, material and equipment availability, congestion, and out-of-sequence work.

Kane et al (cited in Herbsman et al, 1990) classified factors affecting construction productivity into two main groups: technological factors and administrative factors. The technological factors encompass those related mostly to the design of the project; the administrative group factors relate to the management and construction of the project. Technological factors comprise sub-groups such as design factors, material factors and location factors. Administrative factors comprise sub-groups, such as construction methods and procedural factors, equipment factors, labour factors, and social factors.

Heizer and Render (1990) classified factors influencing site productivity into 3 groups: labour characteristic factors; project work conditions factors; and nonproductive activities. Olomolaiye et al (1998) stated that factors affecting construction productivity are rarely constant, and may vary from country to country, from project to project, and even within the same project, depending on circumstances. They classified factors influencing construction productivity into 2 categories: external and internal, representing those outside the control of the firm's management, and those originating within the firm.. External factors included the nature of the industry, construction client knowledge of construction procedure, weather, and level of economic development. Internal factors included management, technology, labour, and labour unions. Enshassi et al 2006, Enshassi et al 2007, and Al Haddad 2007 stated that among the problems which the Palestinian construction industry is facing are material supply schedules and project scheduling techniques. Although a number of training courses were conducted to local contractors, these training efforts did not focus enough on the abilities to use project scheduling techniques such as Microsoft project and Primavera. Therefore training effort should also be tailored to improve methods of studying productivity and ways of productivity improvement on construction sites.

\section{Research method}

This research is based on a survey designed to gather all necessary information in an effective way. The survey presents 45 productivity factors generated on the basis of related research work on construction productivity (Thomas and Sanders, 1991; Guhathakurtal and Yates, 1993; Lim and Alum, 1995; Lema, 1995; Olomolaiye et al, 1996; Heizer and Render, 1996; Olomolaiye et al, 1998; Kaming, et al, 1998; Teicholz, 2001; Wachira, 1999; Rojas and Aramvareekul, 2003), together with input, 
revision and modifications by local experts. These factors were divided into 10 groups based on previous literature and as advised by local experts: manpower, leadership, motivation, time, materials/tools, supervision, project, safety, quality, and external factors.

The studied target population includes contractors who hold valid registration from the contractors union in building specialisation within the Gaza Strip. The total number of contractors who have valid registration under the first, second and third categories are represented by 105 companies. The main criteria for classification are related to the company's previous experience; capital; the value of executed projects, staffing, and financial situation during the last 10 years. The first class comprises 41 firms, the second class 47 firms, and the third class 17 firms. A systematic random sample was selected to ensure a representative sample of all contractors, using the following formula (Hogg and Tannis, 1997):

$$
\begin{aligned}
& m=\frac{Z^{2} \times P^{*} \times\left(1-P^{*}\right)}{\varepsilon^{2}} \\
& n=\frac{m}{1+\frac{m-1}{N}},
\end{aligned}
$$

where: $m$ - sample size of unlimited population; $n-$ sample size of limited population; $Z$ - value (eg 1,96 for $95 \%$ confidence level); $P^{*}$ - degree of variance between the elements of population $(0,5) ; \varepsilon-$ maximum error of the point estimate,

$$
\begin{gathered}
m=\frac{(1,96)^{2} \times 0,5 \times(1-0,5)}{(0,05)^{2}}=384,16=385 ; \\
n=\frac{385}{1+\frac{385-1}{105}}=82,67=83
\end{gathered}
$$

A total of 83 contracting companies within the Gaza Strip were surveyed; 33 first-class contractors, 37 secondclass contractors, and 13 third-class contractors. The overall response to the survey comprised a total of 76 completed questionnaires, representing approx $91 \%$ response rate. This result has been achieved by continuous following-up and close personal contact with contractors. The respondents are recognised experts from their respective organisations (mostly directors and general managers) with at least 10 years' construction experience. The sample was selected randomly from each level of the three contractor's categories. The contractor's union list is ordered by the company number, and 3 lists of contractors were prepared to present the first, second and third categories. The random selection among the three lists was done by using non-replacement random selection.

An ordinal measurement scale, which is a ranking of rating data that normally use integers in ascending or descending order, was used in this study. The numbers assigned to the agreement scale $(5,4,3,2,1)$ do not indicate that the intervals between the scales are equal, nor do they indicate absolute quantities (Naoum, 1998). The respondents were asked to rank the factors affecting labour productivity according to the degree of importance (1 - affects with little degree; 2 - affects something; 3 - affects with average degree; 4 - affects with large degree; 5 - affects with very large degree). For analysing data by ordinal scale, an importance index (I) was used. This index was computed by the following equation (Lim et al, 1995):

Importance index $=\frac{5 n 5+4 n 4+3 n 3+2 n 2+n 1}{5(n 1+n 2+n 3+n 4+n 5)} * 100$,

where: $n 1$ - number of respondents who answered "little effect"; $n 2$ - number of respondents who answered "some effect"; $n 3$ - number of respondents who answered "average effect"; $n 4$ - number of respondents who answered "high effect"; $n 5$ - number of respondents who answered "very high effect".

The importance index (I) for all factors was calculated. The group index was calculated by taking the average of factors in each group.

\section{Results and discussion}

In this study, 45 factors negatively affecting labour productivity in building construction of the Gaza Strip have been identified and ranked according to their relative importance. These factors have been classified into 10 groups: manpower, leadership, motivation, time, materials/tools, supervision, project, safety, quality, and external factors.

\section{Manpower group}

Table 1 illustrates the ranking of the 8 factors in the group related to manpower. The results show that the most important factor negatively affecting the productivity is lack of labour experience, followed by labour disloyalty, labour dissatisfaction, misunderstanding among labour, lack of competition, increase in labourer age, labour absenteeism, and labour personal problems.

Table 1. Ranking factors under manpower group

\begin{tabular}{lcc} 
Factors & Imp. index & Rank \\
\hline Lack of labour experience & 84,21 & 1 \\
Labour disloyalty & 78,55 & 2 \\
Labour dissatisfaction & 72,11 & 3 \\
Misunderstanding among labour & 71,58 & 4 \\
Lack of competition & 66,84 & 5 \\
Increase of labourer age & 62,63 & 6 \\
Labour absenteeism & 55,00 & 7 \\
Labour personal problems & 54,74 & 8
\end{tabular}

The surveyed contractors ranked 'lack of labour experience it the first position, with an importance index value of 84,21 . This factor was also ranked it the second position among all 45 factors, negatively affecting labour productivity (Table 11), which indicates that lack of labour experience has a very high effect on productivity. This result is supported by Paulson (1975), who found that experience of the craftsmen affects labour productivity. This result is also supported by Heizer and Render (1990), who confirmed that experience of workforce affects job site productivity. This result is justified, as experience improves both the intellectual and physical abilities of labour 
which consequently increase labour productivity. 'Labour disloyalty' had a high effect on labour productivity, and was ranked in the second position in the manpower group, with an importance index of 78,55. 'Labour disloyalty' also ranked seventh among all 45 factors negatively affecting labour productivity (Table 11).

Furthermore, results indicated that 'misunderstanding among labour' has an average effect on labour productivity, as this factor was ranked 17 among all factors negatively affecting labour productivity. This result is justified, as misunderstanding among labour creates disagreement among labour about responsibilities and work bounds of each labourer, which leads to a lot of mistakes in work, and consequently decreases labour productivity.

Findings also show that contractors' respondents rated 'lack of competition' as having an average effect on labour productivity; this factor ranked at position 25 of all 45 factors negatively affecting productivity. Findings also show respondents rated 'increase of labourer age' as having an average effect on labour productivity, with this factor being ranked at number 30 of all factors negatively affecting labour productivity (Table 11). Heizer and Render (1990) support this result, citing that the age of the workforce affects job site productivity. This result is justified, as labour speed, agility, and strength decline over time and contributes to a reduced productivity.

'Labour absenteeism' in particular had a low effect on labour productivity, ranking at position 41 of all factors negatively affecting productivity. This result might be justified, given the transient nature of the local workforce and the ease with which construction contractors could hire additional labour to cover absenteeism. Personal problems are not considered to be as instrumental as other factors, and ranked in position 42 of all factors negatively affecting labour productivity. This result might be justified, as personal problems cause only mental distraction for labour, and mental distraction affects labour safety more than labour productivity.

\section{Leadership group}

The results in Table 2 illustrate the ranking of the 3 factors under leadership group. Lack of labour surveillance was ranked first; misunderstanding between labour and superintendents was ranked second; and lack of periodic meeting with labour was ranked third. Lack of labour surveillance has a high effect on labour productivity (imp. index $=83,42$ ), and ranked in position 3 of all 45 factors negatively affecting labour productivity (Table 11). This result is justified, as lack of labour surveillance increases labour mistakes at work, as well as delaying corrective action for these mistakes.

Misunderstanding between labour and superintendents has a high effect on labour productivity (imp. index $=80,26$ ), and ranked in position 4 of all factors negatively affecting labour productivity. This result is justified, as misunderstanding between labour and superintendents creates bad relations between them. Such misunderstandings have adverse effects on labour mood, and consequently decrease productivity. Finally, lack of periodic meetings with labour is not considered to be as in- strumental as other factors on labour productivity, and ranked in position 38 of all factors negatively affecting labour productivity. This result might be justified, because building projects within the Gaza Strip are small and problems facing work can be discussed at any time with superintendents; therefore there is no need for periodic meetings with labour to discuss these problems.

Table 2. Ranking factors under leadership group

\begin{tabular}{lcc} 
Factors & Imp. index & Rank \\
\hline Lack of labour surveillance & 83,42 & 1 \\
Misunderstanding between labour/ & & \\
superintendents & 80,26 & 2 \\
Lack of periodic meeting with labour & 56,84 & 3
\end{tabular}

\section{Motivation group}

Table 3 indicates the ranking of 6 factors under the group related to motivation. These factors were placed in descending order according to their importance: payment delay, lack of financial motivation system, lack of labour recognition programs, non-provision of transportation means, lack of places for eating and relaxation, and lack of training sessions. Results demonstrate that payment delay has a high effect on labour productivity (imp. in$\operatorname{dex}=78,68$ ), and ranked in position 6 of all 45 factors negatively affecting labour productivity. This result is justified, as payment delay has a very bad effect on labour mood, and consequently decreases its productivity. Contractors believed that lack of financial motivation system has greater negative impact on labour productivity than the lack of labour recognition programs, and ranked 'lack of financial motivation system' in position 21, while 'lack of labour recognition programs' was ranked in position 32 of all factors negatively affecting productivity. Motivation is essential to labour, as it gives site workers satisfaction such as achievement, sense of responsibility and pleasure of the work itself.

Table 3. Ranking factors under motivational group

\begin{tabular}{lcc} 
Factors & Imp. index & Rank \\
\hline Payment delay & 78,68 & 1 \\
Lack of financial motivation system & 68,95 & 2 \\
Lack of labour recognition programs & 61,84 & 3 \\
Non-provision of transport means & 56,05 & 4 \\
Lack of places for eating and relaxation & 55,53 & 5 \\
Lack of training sessions & 50,26 & 6
\end{tabular}

Non-provision of transport means and places for eating and relaxation is not considered to be as instrumental as other factors on labour productivity, and ranked in positions 39 and 40 respectively among all factors negatively affecting productivity. This result is not supported by Lema (1995), who mentioned that non-financial benefits such as transport, meals, and uniforms have a high effect on labour productivity. These results might be justified within the Gaza Strip because its small area means transportation to any place within the Gaza Strip can be made available easily; therefore there is no need to pro- 
vide transport to labour. Additionally, Palestinian labour is not sensitive to their place of eating; according to their culture, any place can be used for eating, so there is no need to provide a special place for eating and relaxation. Furthermore, findings illustrate that a lack of training sessions is not considered to be as instrumental as other factors on labour productivity, and was ranked 44 of all negative factors. Surveyed contractors illustrate there is no need for training sessions, and labour can be trained more effectively on site by working closely with experienced workers.

\section{Time group}

Table 4 shows the 5 factors in the group related to time; these were ranked according to their importance in affecting labour productivity as follows: working for 7 days per week without holiday was ranked first; misuse of time schedule was ranked second; method of employment (using direct work system) was ranked third; increasing workforce to accelerate work was ranked fourth; and work overtime was ranked fifth.

Table 4. Ranking factors in the time group

Factors

Working 7 days per week without taking a holiday

Misuse of time schedule

Method of employment (using direct work system)

Increasing No of labour in order to accelerate work

Work overtime

Working 7 days per week without holiday has a high effect on labour productivity, while working additional hours during the working day has an average effect. Hinze (1999) supported these results, stating that working additional days and hours has a negative impact on labour productivity. These results are not surprising, because working additional days and hours creates an adverse effect on the motivation and physical strength of labour, thus decreasing their productivity. However, the impact of working additional hours for a short period may be not noticeable, or non-existent.

Results also demonstrate that 'misuse of time schedule' has a high negative impact on labour productivity. This result is acceptable, as good use of time schedule leads to many advantages such as continuous flow of work; reduced volume of rework; minimisation of confusion and misunderstanding. Using a daily work system instead of a unit rate system has an average negative effect on labour productivity, and ranked in position 31 of all 45 factors negatively affecting labour productivity (Table 11). This result is justified, as the labour desire to work by unit rate system to earn more money. Therefore labour works too hard to finish the greatest volume of work when working by the unit rate system.
Increasing the workforce on the construction site has a moderate effect on labour productivity, and is ranked in position 28 of all factors negatively affecting labour productivity. This result was also supported by Hinze (1999), who mentioned that increasing the workforce on a construction site has an adverse impact on labour productivity. This result is justified, as increasing the workforce on a construction site causes overcrowding of labour and interference between labour and gangs, which consequently reduces labour productivity.

\section{Materials/tools group}

The results in Table 5 demonstrate 3 factors in the materials/tools group; these were ranked according to their importance in effecting labour productivity as follows: material shortages; tool and equipment shortages; and unsuitability of materials storage location. These findings show that a material shortage is the most important of all factors negatively affecting labour productivity. Material shortage was ranked in the first position of all 45 factors negatively affecting labour productivity, which is understandable, as work cannot be accomplished without necessary materials. Material shortages rated in the first position among factors affecting labour productivity in the US, UK, Indonesia, Nigeria, Singapore, and Kenya (Guhathakurta and Yates, 1993; Lim and Alum, 1995; Olomolaiye et al, 1996). This result is justified in the Gaza Strip, as most materials used in construction projects are imported from Israel; therefore any closure of crossing points between the Gaza Strip and Israel stop work on all construction projects.

Table 5. Ranking factors under materials/tools group

\begin{tabular}{lcc} 
Factors & Imp. index & Rank \\
\hline Material shortages & 89,47 & 1 \\
Tool and equipment shortages & 75,26 & 2 \\
Unsuitability of materials storage location & 69,21 & 3
\end{tabular}

Results also show that tool and equipment shortages have a high effect on labour productivity, and ranked in position 10 of all factors negatively affecting labour productivity. Tool and equipment shortages also have a high effect in the US, UK, Indonesia, and Nigeria (Guhathakurta et al, 1993; Olomolaiye et al, 1996). This result might be justified, as labour needs a minimum number of tools and equipment to work effectively. If there is lack of equipment and/or tools, productivity will decrease. Results also illustrate that unsuitability of materials storage location has an average effect on labour productivity, and is ranked in position 20 of all factors negatively affecting labour productivity. This result was supported by Thomas and Sanders (1991), who stated that size and organisation of materials storage location have a significant impact on masonry productivity. This result is justified as labour needs more time to fetch required materials from unsuitable storage locations, which negatively affects productivity. 


\section{Supervision group}

All supervision factors have a high impact on productivity, and were ranked according to their importance as follows: drawings and specifications alteration during execution; inspection delay; rework; and supervisors' absenteeism (Table 6). Drawings and specification alteration during execution is the most important factor in supervision factors group, and is ranked within the 10 most important factors negatively affecting productivity, with an importance index value of 80 . This result is supported by Thomas (1999), who stated there is a $30 \%$ loss of efficiency when work changes are being performed. This result can be interpreted as changes of specifications and drawings that require additional time for adjustments of resources and manpower so the change can be met. Labour morale is also affected by extensive numbers of changes.

Table 6. Ranking factors under supervision group

Factors Imp. index Rank

Drawings and specifications alteration during execution

Inspection delay

Rework

Supervisors' absenteeism

$\begin{array}{ll}80,00 & 1 \\ 77,63 & 2 \\ 75,00 & 3 \\ 71,84 & 4\end{array}$

Inspection delay is the second important factor in supervision factors group, and is also ranked within the 10 most important factors negatively affecting productivity. Inspection delay also has a high impact in the US, UK, Nigeria, and Indonesia (Guhathakurta et al, 1993 Olomolaiye et al, 1996). This result is justified, as work inspection by a supervisor is an essential process to proceed in work; for example, as contractors cannot cast concrete before inspection of formwork and steel work, inspection delay contributes to delays in work activities.

Supervisors' absenteeism, the last factor in the supervision factors group, is ranked in position 15 of all factors negatively affecting labour productivity. This is not surprising in Gaza Strip projects, as absenteeism of supervisors stops work totally in activities that require attendance of supervisors, such as casting concrete and backfilling. Additionally, supervisors' absenteeism delays inspection of ready work, which, in turn, leads to delay in the commencement of new work.

\section{Project group}

The most important factor in this group was working within a confined space, followed by interference; construction method; and type of activities in project (Table 7). Working within a confined space was ranked in position 19 of 45 factors negatively affecting labour productivity. This result is supported by Thomas and Sanders (1991), in which it was reported that one of the common reasons for low productivity is working within a confined space. This result might be justified, as confined spaces reduce free movement of labour, and consequently reduce their productivity.
Table 7. Ranking factors under the project group

\begin{tabular}{lcc} 
Factors & Imp. index & Rank \\
\hline Working within a confined space & 70,26 & 1 \\
Interference & 67,11 & 2 \\
Construction method & 62,11 & 3 \\
Type of activities in the project & 61,58 & 4
\end{tabular}

Interference has an average impact on labour productivity, and was ranked in position 24 of all factors. Interference also has a significant impact on labour productivity in the US, UK, Nigeria, and Indonesia (Guhathakurta and Yates, 1993; Olomolaiye et al, 1996). Interference between gangs and workers is caused by mismanagement on construction sites, with steel fixers suffering more of this, possibly because they are more dependent on other trades. For example, if the carpenters have not completed the formworks, steel fixers will have to wait before fixing the reinforcement rods.

Results also indicate that the construction method and type of activities in the project are not considered to be as instrumental as other factors, and were ranked in positions 32 and 34 of all 45 factors negatively affecting labour productivity. This result is not supported by Thomas and Sanders (1991), who found that construction method and project features have a high impact on labour productivity. This result might be justified, because building projects within the Gaza Strip are not complex and are small in size. Therefore activities in different projects largely have the same features, and there is no major difference between methods used in construction.

\section{Safety group}

The result in Table 8 depicts that the 7 factors under the safety group have been placed in descending order as follows: accidents, violation of safety precautions, insufficient lighting, bad ventilation, working at high places, unemployment of safety officer on the construction site, and noise.

Table 8. Ranking factors under safety group

\begin{tabular}{lcc} 
Factors & Imp. index & Rank \\
\hline Accidents & 72,37 & 1 \\
Violation of safety precautions & 67,63 & 2 \\
Insufficient lighting & 64,74 & 3 \\
Bad ventilation & 61,32 & 4 \\
Working at high places & 58,68 & 5 \\
Unemployment of safety officer on & & \\
the construction site & 53,16 & 6 \\
Noise & 48,42 & 7
\end{tabular}

Accidents have a high impact on labour productivity, and ranked in position 13 of 45 factors negatively affecting labour productivity. These results were supported by Thomas and Sanders (1991), who stated that accidents have a significant impact on labour productivity. There are 3 types of accidents:

- Accidents resulting in the death of an injured worker; this type of accident lead to total stoppage of work a number of days. 
- Accidents that cause an injured labourer to be hospitalised for at least $24 \mathrm{~h}$; this type of accident decreases productivity of the gang in which this injured labourer was working.

- Small accidents that result from nails and steel wires; these affect productivity in only a few cases.

Insufficient lighting has an average impact on labour productivity, and ranked in position 27 of all 45 factors negatively affecting labour productivity (Table 11). This result is justified, as labour needs sufficient lighting to work effectively, and consequently, insufficient lighting has a negative impact on labour productivity. Bad ventilation and working at high places are not considered to be as instrumental as other factors, and ranked in positions 35 and 37 of all factors negatively affecting labour productivity. This result is justified, as most building projects within the Gaza Strip are upgrade and have a small number of storeys; therefore labour seldom face these problems in building projects within the Gaza Strip.

The results also indicate that unemployment of the safety officer on construction site is not considered to be as instrumental as other factors on labour productivity. This result is justified within the Gaza Strip, as contractors seldom employ safety officers in building projects; therefore they are not aware of the importance of employing a safety officer on construction sites. It should be noted that employment of a safety officer on construction sites helps the labour to understand the required safety regulations, and then to follow them. This prevents, or at least reduces, the number of accidents, which consequently improves labour productivity. Noise also is not considered to be as instrumental as other factors on labour productivity, and ranked in the last position of all factors affecting productivity. This result is justified, as equipment and tools used in building projects within the Gaza Strip cause little noise.

\section{Quality group}

The results in Table 9 depict the 3 factors under the quality factors group; these are placed in descending order as follows: inefficiency of equipment, poor quality of raw materials, and high quality of required work. The surveyed companies have more tendencies to place inefficiency of equipment as the most important factor within this group, with an importance index value of 71.585. This result might be justified, as the productivity rate of inefficient equipment is low, and this consequently has an adverse impact on labour productivity depending on this equipment. The type of equipment also affects labour productivity; for example, new and modern equipment has a high productivity rate, while old equipment has a low one, and is subject to large number of breakdowns.

Table 9. Ranking factors in the quality group

\begin{tabular}{lrc} 
Factors & Imp. index & Rank \\
\hline Inefficiency of equipment & 71,58 & 1 \\
Low quality of raw materials & 71,32 & 2 \\
High quality of required works & 67,89 & 3
\end{tabular}

The surveyed companies ranked poor quality of raw materials at position 18 of all factors affecting labour productivity, with an importance index value of 71.32. This result might be justified, as the time needed to build with materials of poor quality is greater than the time needed to build with high quality materials. Additionally, wastage of materials of poor quality is high, particularly during handling. Furthermore, using materials of poor quality leads to poor quality work, which is consequently rejected by the supervisor. Quality of required work has an average impact on labour productivity, and ranked in position 22 of all 45 factors negatively affecting labour productivity. This result is acceptable, as time required to finish work depends greatly on allowed tolerance of required work; ie when the tolerance of required work is very low, labour work slowly in order to avoid unacceptable mistakes.

\section{External group}

The results in Table 10 demonstrate that 2 factors of the external factors group have been ranked according to their importance as follows: weather changes and augmentation of government regulations related to the construction sector. Weather changes have an average impact on labour productivity, and ranked in position 29 of all factors affecting the productivity. Thomas and Sanders (1991) support this result in their study of factors affecting productivity in the US. The temperature in the Gaza Strip is moderate; therefore, increase and decrease of temperature have a low effect on labour productivity. However, adverse winter weather such as winds and rains reduce labour productivity; particularly external work such as formwork, steel work, concrete casting, external plastering, external painting, and external tiling. Adverse weather sometimes stopped work totally.

Table 10. Ranking factors under external group

\begin{tabular}{lcc} 
Factors & Imp. index & Rank \\
\hline Weather changes & 63,95 & 1 \\
Augmentation of Government regulations & 60,79 & 2
\end{tabular}

Augmentation of government regulations related to the construction sector is not considered to be as instrumental as other factors, and ranked in position 36 of all factors negatively affecting labour productivity. This result might be justified within the Gaza Strip, where government regulation of construction projects has been subjected to minor changes only during the last years.

\section{Overall ranks of all factors negatively affecting labour productivity}

The results in Table 11 depict that the most 5 important factors negatively affecting labour productivity are: material shortages; lack of labour experiences; lack of labour surveillance; misunderstanding between labour and superintendents; and drawings and specifications alteration during execution, with important indexes values of 89.47, 
Table 11. Overall ranking of factors negatively affecting labour productivity

Factors

Material shortages

Lack of labour experience

Lack of labour surveillance

Misunderstanding between labour

and superintendents

Drawings and specifications alteration

during execution

Payment delay

Labour disloyalty

Inspection delay

Working 7 days per week without

taking a holiday

Tool and equipment shortages

Rework

Misuse of time schedule

Accidents

Labour dissatisfaction

Supervisors' absenteeism

Inefficiency of equipment

Misunderstanding among labour

Low quality of raw materials

Working within a confined space

Unsuitability of materials storage

location

Lack of financial motivation system

High quality of required work

Violation of safety precautions

Interference

Lack of competition

Method of employment

(using direct work system)

Insufficient lighting

Increasing number of labours

Weather changes

Increase of labourer age

Working overtime

Lack of labour recognition programs

Construction method

Type of activities in the project

Bad ventilation

Augmentation of Government regulations

Working at high places

Lack of periodic meeting with labour

Non-provision of transport means

Lack of place for eating and relaxation

Labour absenteeism

Labour personal problems

Unemployment of safety officer on

the construction site

Lack of training sessions

Noise

Imp. index Rank

$\begin{array}{ll}89,47 & 1 \\ 84,21 & 2 \\ 83,42 & 3\end{array}$

$80,26 \quad 4$

$80,00 \quad 5$

$78,68 \quad 6$

$78,55 \quad 7$

$77,63 \quad 8$

$76,58 \quad 9$

$75,26 \quad 10$

$75,00 \quad 11$

$74,74 \quad 12$

$72,37 \quad 13$

$72,11 \quad 14$

$71,84 \quad 15$

$71,585 \quad 16$

$71,58 \quad 17$

$71,32 \quad 18$

$70,26 \quad 19$

$69,21 \quad 20$

$68,95 \quad 21$

$67,89 \quad 22$

$67,63 \quad 23$

$67,11 \quad 24$

$66,84 \quad 25$

$65,79 \quad 26$

$64,74 \quad 27$

$64,47 \quad 28$

$63,95 \quad 29$

$62,63 \quad 30$

$62,37 \quad 31$

$61,84 \quad 33$

$62,11 \quad 32$

$61,58 \quad 34$

$61,32 \quad 35$

$60,79 \quad 36$

$58,68 \quad 37$

$56,84 \quad 38$

$56,05 \quad 39$

$55,53 \quad 40$

$55,00 \quad 41$

$54,74 \quad 42$

$53,16 \quad 43$

$50,26 \quad 44$

$48,42 \quad 45$
$84.21,83.42,80.26$, and 80 respectively. On the other hand, results indicate that labour absenteeism, labour personal problems, unemployment of safety officer on the construction site, lack of training sessions, and noise were the lowest factors negatively affecting labour productivity, with important index values of 55, 54.74, 53.16, 50.26 , and 45 respectively.

\section{Ranking groups negatively affecting labour produc- tivity}

The results in Table 12 demonstrate the ranking of 10 groups that affect labour productivity. It is noted that the materials/tools factors group was ranked first of 10 factor groups negatively affecting labour productivity; this result is justified, as any project cannot be executed without availability of materials and tools. The current political situation within the Gaza Strip causes frequent closures of crossing points between the Gaza Strip and Israel, which results in shortages of materials and some tools in the local market, which affects labour productivity too much. On the other hand, the safety factors group was ranked last of the 10 groups affecting labour productivity, which can be readily interpreted as that the government shows little concern about safety, and that contracting companies have little awareness of the impact of safety factors on labour productivity. Therefore these safety factors were rated as having only an average or low impact on labour productivity.

Table 12. Ranking factors negatively affecting productivity among groups

Factors groups Imp. index Rank

Materials / Tools factors

$77,98 \quad 1$

Supervision factors

$76,12 \quad 2$

Leadership factors

73,51

Quality factors

70,36

68,79

Manpower factors

68,16

Project factors

65,26

62,38

61,85

Motivation factors

60,90

1

Safety factors

10

\section{Conclusions}

Productivity is considered the main value-adding function within the construction sector. The aim of this research was to identify factors affecting labour productivity in building projects, and to rank these according to their relative importance from the contractor's viewpoint within the Palestinian construction industry. A total of 45 factors were identified in this study, with identification of factors influencing construction productivity being based on a careful review of literature and suggestions from local experts in building construction. 
The results indicated that the main 10 factors negatively affecting labour productivity are:

1. Materials shortages.

2. Lack of labour experiences.

3. Lack of labour surveillance.

4. Misunderstanding between labour and superintendents.

5. Drawings and specification alteration during execution.

6. Payment delay.

7. Labour disloyalty.

8. Inspection delay.

9. Working seven days per week without holiday.

10. Tool / equipment shortages.

Furthermore, 45 factors considered in the study were divided into 10 groups, which were ranked according to their importance index:

1. Materials/tools factors group.

2. Supervision factors group.

3. Leadership factors group.

4. Quality factors group.

5. Time factors group.

6. Manpower factors group.

7. Project factors group.

8. External factors group.

9. Motivation factors group.

10. Safety factors group.

It is recommended that contracting companies should provide a materials supply schedule for each project. This schedule should include the time required to supply materials and the availability of materials on the local market to furnish the required materials in time. Contracting companies should also select a suitable storage location for purchased materials in each project, which should be easily accessible and close to constructed buildings to avoid wastage of labour time for multiple-handling materials. Contracting companies have to pay more attention to the quality of construction materials and tools used in their projects, as using appropriate materials and tools reduces both the time taken to finish the work and wastage of materials. Using appropriate materials and tools also has a positive effect on the quality of work, which consequently improves labour productivity. Project management has to assign or recruit the right people to do the job, and should also keep a close eye on labour work to make sure they understand site instructions. Furthermore, it ought to maintain friendly relations with labour and let them know they are important to the organisation, and involve them in decisions affecting their jobs, such as process improvements.

It is necessary to use project scheduling techniques (such as computer-aided construction project management) in each project to optimise the times of related activities, and to ensure that works allow continuous task performance, so as to reduce idleness of the labour force to a minimum. It is important for each contracting company to adopt motivational or personnel management measures to boost workers' morale. For example, tying compensation to performance; ensuring that pay, fringe benefits, safety, and working conditions are all at least adequate; and enlarging the jobs to include challenge, variety, wholeness, and self-regulation. Contracting companies have to conduct productivity studies at the activity/operation level, such as studying factors affecting labour productivity and labour productivity measurement to describe the detailed tasks performed for an activity/operation by individual or group in order to establish problem areas and propose ways to improve labour productivity. Contracting companies are also encouraged to keep historical data of productivity studies in completed projects to improve the effectiveness and accuracy of cost estimation of future projects.

It is necessary to conduct training courses and seminars in the topics that will improve productivity in construction projects. The training effort should be tailored to improve abilities to use project scheduling techniques such as Microsoft project and Primavera. The training effort should also be tailored to improve methods of studying productivity and ways of productivity improvement on construction sites. There is a need to increase the number of trade schools that focus on teaching construction trades such as block work, formwork, painting, plastering, plumbing etc to improve the abilities and skills of craftsmen working on construction projects. More efforts should be made by contracting companies to benefit from what other developed countries have achieved through technology transfer and best use of benchmarking.

\section{References}

AL HADDAD, A. A. (2007) Construction materials management system for Gaza Strip building construction. Unpublished MSc thesis, Islamic University of Gaza, Palestine.

ENSHASSI, A.; HALLAQ, K.; and MOHAMED, S. (2006) Causes of contractors' business failure in developing countries: the case of Palestine. Journal of Construction in Developing Countries, 11(2), p. 1-14.

ENSHASSI, A.; MOHAMMED, SH. MAYER, P. E.; ABEED, K. Benchmarking masonry labor productivity. International Journal of Productivity and Performance Management (Accepted for publication 2007).

GUHATHAKURTA, S.; and YATES, J. (1993) International labour productivity. Cost Engineering Journal, 35(1), p. $15-25$.

HEIZER, J.; RENDER, B. (1990) Production and operations management "strategic and tactical decisions". Prentice Hall, New Jersey.

HERBSMAN, Z.; and ELLIS, R. (1990) Research of factors influencing construction productivity. Construction Management and Economics, 32(8), p. 49-61.

HINZE, J. W. (1999) Construction planning and scheduling. Prentice-Hall, New Jersey.

HOGG, R. V.; TANNIS, E. A. (1997) Probability and statistical inferences. Prentice Hall.

KAMING, P. F.; HOLT, G. D.; KOMETA, S. T.; OLOMOLAIYE, P. O. (1998) Severity diagnosis of productivity problems - reliability analysis. International Journal of Project Management, 16(2), p. 107-113.

LEMA, N. M. (1995) Construction of labour productivity modeling. University of Dar Elsalaam.

LIM, E. C.; ALUM, J. (1995) Construction productivity: issues encountered by contractors in Singapore. International Journal of Project Management, 13(1), p. 51-58. 
MADI, I. M. (2003) Essential factors affecting accuracy of cost estimation of building contractors. Unpublished MSc thesis, Islamic University - Gaza, Palestine.

MAS (Palestinian economic policy research institute), 2001. Economic monitoring report. Available from Internet: $<$ www.palecon.org/masdir/monitor/monitor.html>.

NAOUM, S. G. (1998) Dissertation research and writing for construction students. Butterworth-Heinemann.

OGLESBY, C. H.; PARKER, H. W.; HOWELL, G. A. (2002) Productivity improvement in construction. McGraw-Hill, USA.

OLOMOLAIYE, P.; JAYAWARDANE, A.; HARRIS, F. (1998) Construction productivity management. Chartered Institute of Building, UK.

OLOMOLAIYE, P.; KAMING, P.; HOLT, G.; HARRIS, F. (1996) Factors influencing craftsmen's productivity in Indonesia. International Journal of Project Management, 15(1), p. 21-30.

PASSIA (2002) Jerusalem, Palestine.

PAULSON, B. C. (1975) Estimation and control of construction labour costs. Journal of Construction Division, ASCE, 101 (CO3), p. 623-633.

PCBS (the Palestinian central bureau of statistics) (2004) Number of enterprises and persons engaged for construction contractors (1995-2000).

PECDAR (1997) Housing in Palestine. Palestine.
PILCHER, R. (1997) Principles of construction management. McGraw-Hill, London.

ROJAS, M. E.; ARAMVAREEKUL, P. (2003) Labour productivity drivers and opportunities in the construction industry. Journal of Management in Engineering, 19(2), p. 78-82.

TEICHOLZ, P. (2001) US Construction labour productivity trends, 1970-1998. Journal of Construction Management and Engineering, ASCE, 127(5), p. 427-429.

THOMAS, H. R. (1999) Construction baseline productivity: theory and practice. Journal of Construction Management and Engineering, ASCE, 125(5), p. 295-303.

THOMAS, H. R.; SANDERS, S. R. (1991) Factors affecting masonry productivity. Journal of Construction Engineering and Management, ASCE, 117(4), p. 626-644.

United Nations (1965) The effect of repetition on building operations and processes on site. New York.

WACHIRA, L. N. (1999) Labour productivity in the Kenyan construction industry. University of Nairobi, Kenya.

WILCOX, S.; STRINGFELLOW, B.; HARRIS, R.; MARTIN, B. (2000) Management and productivity. Transportation research board, committee on management and productivity. Washington, USA.

World Bank (2004) Two years of Intifada, closures and Palestinian economic crisis. Washington, USA.

ZHI, H. (1995) Risk management for overseas construction projects. International Journal of Project Management, 13(4), p. 231-237.

\section{VEIKSNIAI, LEMIANTYS DARBO JĖGOS PRODUKTYVUMĄ STATYBOS PROJEKTUOSE GAZOS RUOŽE}

A. Enshassi, S. Mohamed, Z. Abu Mustafa, P. E. Mayer

S antrauka

Produktyvumas vis dar išlieka viena iš labiausiai dominančių ir svarstomų statybos sektoriaus klausimų. Tai lemia sąnaudų ir išlaidų taupymą, efektyvų išteklių naudojimą. Produktyvumas yra vienas iš svarbiausių tiek išsivysčiusių, tiek besivystančių šalių klausimų. Besivystančios šalys, kurios susiduria su nedarbo problemomis, infliacija ir išteklių stoka, siekia panaudoti turimus išteklius taip, kad būtų pasiektas ekonomikos augimas ir gerètu piliečių gyvenimas. Produktyvumas yra viena iš problemų, turinčių itin daug reikšmės projektuose, vykdomuose Gazos ruože, kadangi ji yra laikoma naujai susiformavusia zona, kurioje artimoje ateityje numatyta vykdyti daug projektu. Šio tyrimo tikslas yra nustatyti veiksnius, veikiančius darbo jègos produktyvumą statybos projektuose ir suskirstyti juos pagal sąlygišką svarbą rangovo požiūriu. Remiantis apklausa, buvo atlikta 45 veiksnių analizė, kurioje buvo išskirti pagrindiniai veiksniai, darantys neigiamą poveikị darbo jègos produktyvumui: tai medžiagu, patirties, kontrolès trūkumas, darbuotojų ir darbų vykdytojų santykiai, brěžinių bei specifikacijų kitimas vykdant darbus.

Reikšminiai žodžiai: produktyvumas, darbo jèga, statybos projektai, gerinimas.

Adnan Ali ENSHASSI. Professor of Construction Engineering and Management in the Civil Engineering Dept at IUG with over 20 years of research, teaching, and consulting experience in various construction project management disciplines. A visiting Professor at Clemson University (USA), Bremen University, Stuttgart Technical University, Berlin Technical University, and Munich Technical University (Germany), Graz University (Austria) and Liverpool University (UK). His research interests include occupational safety and health, contract management, productivity measurement and improvement. Member/Fellow of a number of international professional institutions in USA and UK. He is listed in Marquis "Who's Who in Science and Engineering". The University scientific research prize for Science and Engineering in 2005.

Peter Eduard MAYER. Professor for Project Management and Construction Law at the Technische Universitaet in Munich (Germany). His research interests include new forms of construction contracts, site organization and management. He is also a sworn expert witness at court.

Sherif MOHAMED. Professor and Director of the Centre for Infrastructure Engineering and Management at Griffith University, Queensland (Australia). His research interests: project and construction management. He focuses on the development of theoretical knowledge and operational tools needed for effective process management. Author and co-author of over 100 refereed journal and conference publications in the last 10 years.

Ziad Abu MUSTAFA. Project manager with a local contracting company in Gaza. Experience in the construction industry of more than 10 years. Master degree in Construction Management from IUG. 